\title{
Physiological responses of pirarucu (Arapaima gigas) to acute handling stress
}

\author{
Levy de Carvalho GOMES ${ }^{1}$
}

\begin{abstract}
Pirarucu (Arapaima gigas) is an obligatory air-breathing fish from the Amazon basin. Previous study showed that pirarucu juveniles present a latency period in their response to moderate stress (transportation). Therefore the objective of this study was to verify the effects of a prolonged air exposure stress in lactate, glucose, cortisol, haematocrit, haemoglobin, and liver glycogen in pirarucu. Thirty-six fish were handled by netting and subjected to air exposure for $75-\mathrm{min}$. Six fish were sampled before handling and at 0, 6, 24, 48, and 96h after handling. Fish cortisol, lactate and haematocrit rose after handling, returning to previous unstressed values on the following sampling (6h after handling). Glucose increased significantly after handling and that was maintained for $24 \mathrm{~h}$. There were no changes in haemoglobin and liver glycogen as a consequence of handling. The results demonstrate a quick response when exposed to an acute stressor and a fast recovery, suggesting that pirarucu does not use their glycogen reserves during an acute stress. The results suggest that pirarucu exhibit physiological stress responses to handling similar in magnitude to those previously documented for many teleostean fishes, including salmonids.
\end{abstract}

KEYWORDS: Pirarucu, Stress, Air exposure, Glycogen, Cortisol, Glucose, Lactate, Haematocrit.

\section{Resposta fisiológica de estresse em pirarucu (Arapaima gigas) submetido ao manuseio}

\section{RESUMO}

O pirarucu (Arapaima gigas) é um peixe de respiração aérea obrigatória da bacia Amazônica. Estudo prévio demonstrou que juvenis de pirarucu apresentam um período de latência em sua resposta de estresse a um estresse moderado (transporte). Desta forma, o objetivo deste estudo foi verificar os efeitos de uma exposição aérea prolongada no lactato, glicose, cortisol, hematócrito, hemoglobina e glicogênio do fígado em pirarucu. Trinta e seis peixes foram manuseados com um puçá e expostos ao ar por $75-$ min. Seis peixes foram amostrados antes do manuseio e $0,6,24,48$, e $96 \mathrm{~h}$ após o manuseio. O cortisol, lactato e hematócrito aumentaram após o manuseio, retornando para valores semelhantes ao de antes do manuseio na amostragem seguinte (6 h após o manuseio). A glicose aumentou significativamente após o manuseio e o aumento se manteve até a amostragem de $24 \mathrm{~h}$. Não houve mudança significativa na hemoglobina e no glicogênio como conseqüência do manuseio. Os resultados demonstram que o pirarucu apresenta uma rápida resposta e uma rápida recuperação quando exposto a um estressor agudo e sugerem que o pirarucu não usa suas reservas de glicogênio nesta situação. Os resultados indicam que o pirarucu apresenta uma resposta fisiológica de estresse similar em magnitude com muitos outros teleósteos, incluindo os salmonídeos.

PalaVRaS-ChaVE: Pirarucu, Estresse, Exposição ao ar, Glicogênio, Cortisol, Glicose, Lactato, Hematócrito.

1 Embrapa Amazônia Ocidental, Manaus, AM, Brasil.

Endereço atual: Centro Universitário de Vila Velha, Programa de Mestrado em Ecologia de Ecossistemas, Vila Velha, ES, Brasil. e-mail: levy.gomes@uvv.br. 


\section{INTRODUCTION}

Pirarucu (Arapaima gigas) is an obligatory air-breathing fish that can grow up to $3 \mathrm{~m}$ in length and $200 \mathrm{~kg}$ in weight, endemic to the Amazon Basin (Castello, 2004), it is a representative of one of the oldest fish lineages (Ferraris, 2003). Pirarucu is highly important to Amazonian commercial and subsistence fisheries mainly due to their size and flesh quality (Hrbek et al., 2005). In Brazil, pirarucu landings and the average size of capture have decreased drastically in the last decades, and pirarucu has recently been considered overexploited (Farias et al., 2003). However only in early 2001 the Brazilian government banned all fishing for pirarucu, except in managed areas in the Mamirauá sustainable developmental reserve (Hrbek et al., 2005). On the other hand, pirarucu farming is booming in some South and Central American countries mainly due to its growth rate, reaching from 7 to $10 \mathrm{~kg}$ in a twelve-month culture cycle (Imbiriba, 2001; Pereira-filho et al., 2003).

Pirarucu are frequently exposed to stressors both in the wild and under aquaculture conditions. Juveniles live mainly in lakes closely associated with the floodplain ecosystem (Goulding et al., 2003), in their habitat they are subjected to a diverse range of natural stressors, like high temperatures and seasonal changes in water quality, on the other hand in captivity pirarucu are subjected to transportation, handling, high density, poor water quality, among others.

Previous study demonstrated that pirarucu $(1.5 \mathrm{~kg})$ presented a hyperglycemia pattern without changes in cortisol levels during a transportation procedure (Gomes et al., 2003) whereas small pirarucu $(33 \mathrm{~g})$ show immediate increase in glucose levels and a latency period of 24-h in cortisol release after transport stress (Gomes et al., 2006). This response is different when compared to some temperate fish like salmonids, where the common response to a stressor is the release of adrenaline and cortisol, followed by secondary changes in the blood and tissue metabolites, such as hyperglycemia, hyperlactemia and reduced glycogen content in the liver (Wendelaar Bonga, 1997; Barton, 2000). According to Barton (1997) fish respond to stress in a proportional way that reflects the severity and duration of the stressor. The objective of this work was to verify the physiological responses to a prolonged air exposure stress in pirarucu and help develop more efficient handling and transportation protocols for this species.

\section{MATERIALS AND METHODS}

Pirarucu juveniles were obtained from a commercial supplier and transferred to a 2,000-L indoor tank at the Embrapa fish culture sector (Manaus, Amazonas, Brazil) to train them to accept a commercial (extruded) fish diet. After $100 \%$ acceptance they were reared for 6 months in a 200$\mathrm{m}^{3}$ earth pond and fed five times a week with a commercial food containing $40 \%$ crude protein (Nutron ${ }^{\circledR}$, São Paulo, Brazil).

Fish weighting $3.85 \pm 1.03 \mathrm{~kg}(\mathrm{n}=36)$ were caught from the earth pond and held individually in 2,000-L tanks for a week for acclimation before the stress protocol was initiatted. During acclimation fish were daily fed and $50 \%$ of the tank water $\left(27.8^{\circ} \mathrm{C}, \mathrm{pH} 6.3\right.$, natural photoperiod) was carefully replaced. Fish were starved for 18 -h prior to experimental procedure, after that fish were handled by netting and subjected to air exposure for 75-min, according to a stress protocol used by Gomes et al. (2005). After handling fish were returned to their 2,000-L tank for recovery. During the recovery period fish were fed once a day at 8:00h. Fish stress responses ( $\mathrm{n}=6$ for each sample time) were evaluated before handling (control $[\mathrm{BH}]$ ) and at $0,6,24,48$, and 96-h after handling.

For the sampling procedure fish were quickly captured from the tank and killed by decapitation, according to recommended euthanasia procedure from the guidelines for the use of fishes in research (Nickum et al., 2004). Blood was drawn from the caudal vasculature with heparinized syringes. Blood glucose, haematocrit and haemoglobin were immediately measured, and the remained blood was centrifuged (3,000 rpm, $10 \mathrm{~min})$ and plasma stored at -20 ${ }^{\circ} \mathrm{C}$ for further cortisol analysis. Simultaneously to blood collection liver tissue were excised, promptly frozen in liquid nitrogen and stored at $-80^{\circ} \mathrm{C}$ until glycogen analysis were performed.

Blood glucose was determined by using the digital Advantage ${ }^{\mathrm{TM}}$ blood glucose system (Roche, Germany), validated for use with pirarucu (Gomes et al., 2005). Blood lactate was measured using the digital Lactate-Pro system (Arkray Inc., Japan). Haematocrit values were determined after 10-min centrifugation in micro-haematocrit tubes. Haemoglobin concentration was determined by the cyanmethaemoglobin method (Kampen \& Zijlstra, 1964). Plasma cortisol was measured with an enzyme-linked immunoassay method (ELISA, kit 55050, Human, Germany) validated for use for pirarucu (Gomes et al., 2006), intra-assay coefficient of variation was $4.4 \%$ as for the analytic sensitivity of the assay was $1.1 \mathrm{ng} \cdot \mathrm{dL}^{-1}$.

Liver glycogen concentrations were measured on frozen tissues as outlined by Bergmeyer (1974). Briefly, $100 \mathrm{mg}$ of frozen tissue was homogenized in acetate buffer and glycogen digested with amyloglucosidase in a shaking chamber with temperature control (Technal, TE420) set at $45^{\circ} \mathrm{C}$ during four hours. Glycogen was assayed as free glucose and expressed as $\mu$ moles of glycosyl units per gram of wet tissue.

All results are expressed as means \pm SD. Differences between physiological stress indicators at different samplings times were compared against the control group (before 
handling; $\mathrm{BH})$ by one-way ANOVA and Dunnett's test $(\mathrm{P}<$ $0.05)$. All statistical analyses were performed with the software Sigma Stat 3.0.

\section{RESULTS}

Fish presented a significant rise in their cortisol and lactate (Figure 1) after handling followed by a decrease towards initial levels at 6-h post handling. Cortisol and lactate initial values were $27.4 \pm 8.8 \mathrm{ng} \cdot \mathrm{ml}^{-1}$ and $0.7 \pm 0.1 \mathrm{mmol} . .^{-1}$, respectively. After handling cortisol value was $104.7 \pm 5.7 \mathrm{ng} \cdot \mathrm{ml}^{-1}$, demonstrating a 4 -fold increase when compared to initial values. Lactate presented a similar pattern with a 20 -fold increase after handling. Blood glucose levels increased significantly after handling (Figure 1) and remained elevated for 24-h, declining to initial levels by 48 -h post handling.

No significant changes occurred in liver glycogen (Figure 2 ) and haemoglobin (Figure 3) as a consequence of handling. Haematocrit presented a significant increase after handling, followed by a decline to initial levels by 6 -h post handling.
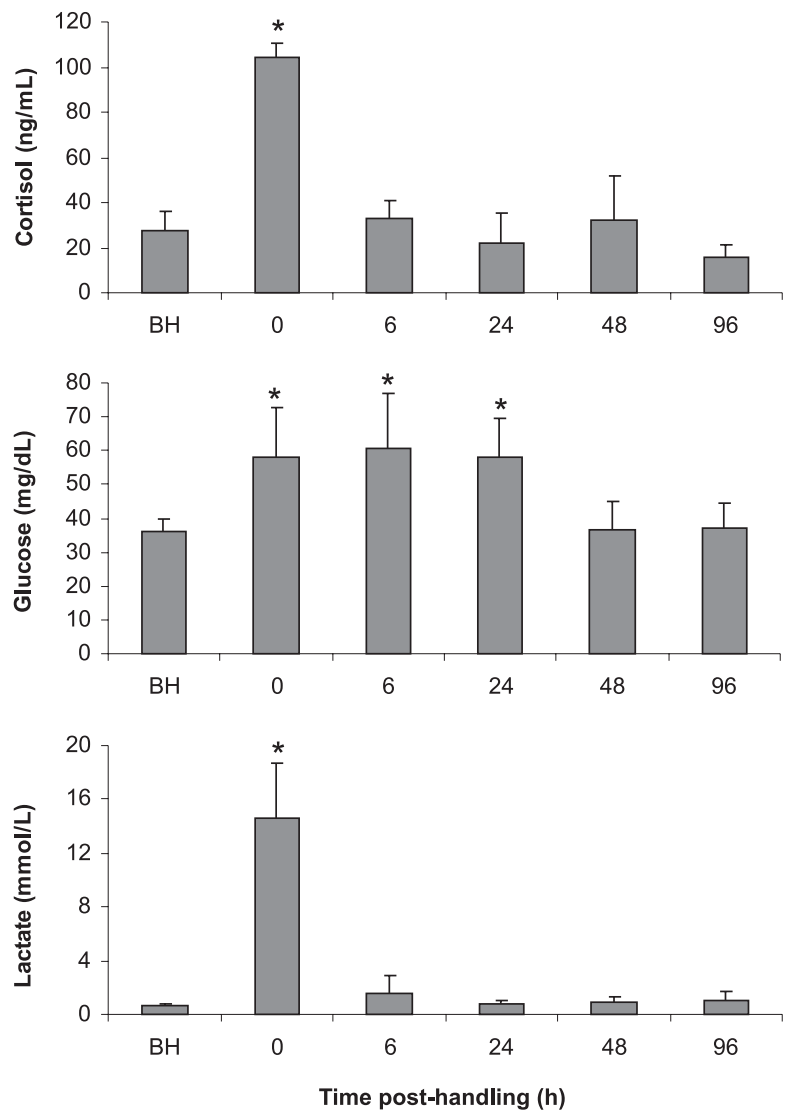

Figure 1 - Cortisol, glucose and lactate of pirarucu (Arapaima gigas) before and after handling stress (75-min of air exposure). Data are mean \pm standard deviation. Columns marked with * are significantly different from the control (before handling - BH) (Dunnett's test; $\mathrm{P}<0.05$ ).

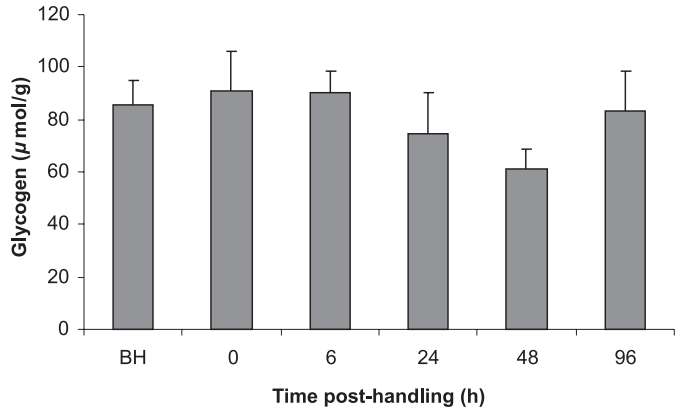

Figure 2 - Liver glycogen of pirarucu (Arapaima gigas) before and after handling stress (75-min of air exposure). Data are mean \pm standard deviation. Columns marked with * are significantly different from the control (before handling - $\mathrm{BH}$ ) (Dunnett's test; $P<0.05$ ).
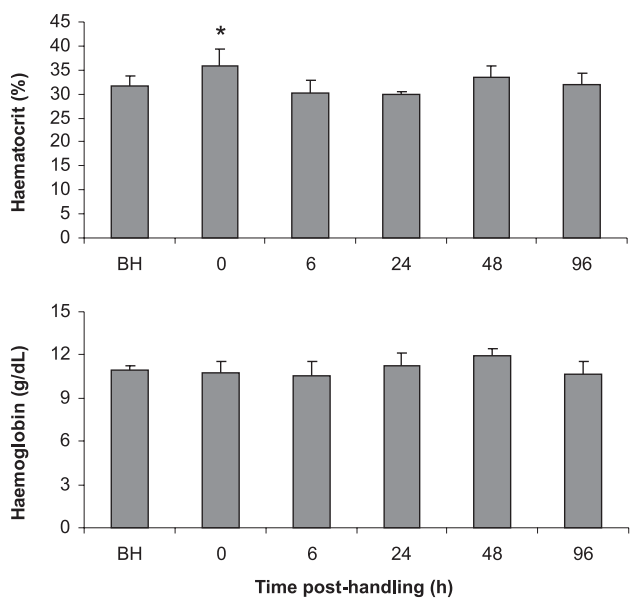

Figure 3 - Haematocrit and haemoglobin of pirarucu (Arapaima gigas) before and after handling stress (75-min of air exposure). Data are mean \pm standard deviation. Columns marked with * are significantly different from the control (before handling - $\mathrm{BH}$ ) (Dunnett's test; $\mathrm{P}<0.05$ ).

\section{DISCUSSION}

Air exposure is a widely used experimental protocol to evaluate acute stress in fish; however the great majority of the studies exposed fish to the air for less than 1-min (Barton, 2000; Sloman et al., 2001; Morales et al., 2005). A few studies exposed fish for more than 10-min, like Bayunova et al. (2002) that exposed Russian sturgeon males (Acipenser gueldenstaedtii) for 30-min in the air. In this study pirarucu were chased, netted and air exposed for 75-min, and did not demonstrate any mortality. The results could be applied to aquaculture practices like catching and handling which constantly expose fish to the air and on the development of short time transportation methods without water. Due to pirarucu's commercial and ecological importance, it is necessary to implement adequate management practices, 
even for situations where there is no immediate fish mortality. Usually a severe stress condition could compromise fish adaptive capacity to the environment and even result in a temporary growth disruption and higher susceptibility to parasites and infections (Wedemeyer, 1996).

Plasma cortisol increase is a primary response during stressful conditions and this hormone is released from the interrenal tissue within minutes of the stressor (Mommsen et al., 1999). In fish an acute stressor can maintain cortisol levels elevated, which may stay that way for a few hours and under chronic stress cortisol may be elevated for days (Sumpter, 1997). Pirarucu show the same trend, as cortisol increases after handling and return to their initial levels 6-h after. Russian sturgeon also presents a cortisol increase after 30-min air exposure followed by a decrease of cortisol levels within 6-h after treatment (Bayunova et al., 2002). On the other hand, Barton (2000) observed that four species of salmonid did not return to their initial condition 6-h after 30-s of air exposure. This study suggests that cortisol was one of the principle steroid released during stress in pirarucu. Cortisol during handling stress in pirarucu increased around 4-fold, which was lower when compared to other fish like gilthead sea bream (Sparatus aurata) which produced a 50-fold increase in cortisol after air exposure (Arends et al., 1999) and the Russian sturgeon with a 60-fold change (Bayunova et al., 2002).

Glucose increases is a secondary stress response induced initially by catecholamines, which allow fish to withstand the stressful situation (Mommsen et al., 1999). Glucose increase was the most pronounced metabolic stress response after pirarucu handling, showing a significantly increase that persisted for 24-h. Increase in glucose values in pirarucu under handling stress were not more than 1-fold, demonstrating a low magnitude in glucose response while for other tropical species like tilapia (Oreochromis mossambicus) glucose values increase 3-fold under acute stress (Vijayan et al., 1997). To account for the maintenance of higher blood glucose during stressful situation fish normally breakdown glycogen from liver, mainly through glycogenolysis (Vijayan et al., 1997). Contrarily, our results show that liver glycogen did not change during an acute stressor, demonstrating that their reserves were not mobilized. The possible explanation is that pirarucu is a voracious carnivorous fish, and was fed before and after the stress protocol to reproduce the normal nutritional state of fish both in the pond and the wild. Therefore a positive energy balance occurred and they had abundant energy reserves for mobilization allowing the fish to cope with the immediate stress without depleting liver glycogen stores. To further confirm this hypothesis Vijayan and Moon (1992) found no change during acute handling stress on liver glycogen content in well-fed rainbow trout (Oncorhynchus mykiss), whereas food deprivation significantly lowered it.

Lactate levels in this study likely rose as a metabolic response to the muscular activity associated with the physical stressors used in this experiment, such as being continuously chased and struggling in a net. According to Gomes et al. (2006) lactate can be an important fuel product to metabolism during stressful situations in pirarucu and may be used as substrate for glucose production. The obtained results confirm this pattern since lactate presented a 20 -fold increase in their levels after handling. Plasma lactate levels in paddlefish increased only 2-3-fold after handling stressor (Barton et al., 1998). In pirarucu the magnitude of lactate response to acute stress is greater than cortisol. The return of lactate concentration to initial values 6-h after the stressor suggests that the organism capacity for lactate use may be enhanced in stressed fish.

According to Morales et al. (2005) changes in secondary stress responses as haematocrit and haemoglobin normally are not displayed in acute handling stress, although it could be more responsive in chronic stress. Our data on haematocrit results are contrary as pirarucu under an acute stress presented a significant increase in their haematocrit after air exposure. Haematocrit increase, as observed, may indicate a small haemoconcentration, which help fish cope with the stress related increase in oxygen demand.

The results suggest that pirarucu exhibit physiological stress responses to handling similar in magnitude to those previously documented for many teleostean fishes, including salmonids and is able to reestablish their initial levels relatively quickly. These results also indicate that a 75-min air exposure were not sufficiently severe to compromise pirarucu ability to compensate for the imposed stress and recover, and should be applied during handling protocols.

\section{ACKNOWLEDGEMENTS}

This study was supported by Embrapa MP2 and CNPq grant \# 475093/2003-8 and \# 506943/2004-6. The author is thankful to Dr. Roger Crescêncio from Embrapa Amazonia Ocidental for their help in sampling and to Dr. Richard P. Brinn for critical review of the manuscript. I also would like to thank the students and technical staff of Embrapa Amazônia Ocidental for their help in the samplings and analytical procedures. The author is a research fellowship recipient from CNPq. 


\section{LITERATURE CITED}

Arends, R.J.; Mancera, J.M.; Munoz, J.L.; Bonga, W; S.E.; Flik, G. 1999. The stress response of the gilthead sea bream (Sparus aurata L.) to air exposure and confinement. Journal of Endocrinology, 163: 149-157.

Barton, B.A. 2000. Salmonid fishes differ in their cortisol and glucose responses to handling and transport stress. North American Journal of Aquaculture, 62: 12-18.

Barton, B.A.; Rahn, A.B.; Feist, G.; Bollig, H.; Schreck, C.B. 1998. Physiological stress responses of the freshwater chondrostean paddlefish (Polyodon spathula) to acute physical disturbances. Comparative Biochemistry and Physiology. A. 120: 355-363.

Bayunova, L.; Barannikova, I.; Semenkova, T. 2002. Sturgeon stress reactions in aquaculture. Journal of Applied Ichthyology, 18: $397-404$

Bergmeyer, H.U. 1974. Principles of enzymatic analysis. Academic press, New York, NY.

Castello, L. 2004. A Method to count pirarucu Arapaima gigas: fishers, assessment, and management. North American Journal of Fish Management, 24: 379-389.

Farias, I.P.; Hrbek, T.; Brinkmann, H.; Sampaio, I.; Meyer, A. 2003. Characterization and isolation of DNA microsatellite primers for Arapaima gigas, an economically important but severely overexploited fish species of the Amazon basin. Molecular Ecology Notes, 3: 128-130.

Ferraris, C.J.; Jr. 2003. Arapaimidae. In: R.E. Reis; S.O. Kullander; C.J. Ferraris Jr. (Eds.). Check list of the freshwater fishes of South and Central America. Edipucrs, Porto Alegre, 31pp.

Gomes, L.C.; Chagas, E.C.; Crescêncio, R.; Pessoa, M.A.; Silva, A.L.F.; Carvalho, E.S.; Junior, G.A.; Brito, M.V.T.; Porto, M.S.A. 2005. Validation of a simple portable instrument for measurement of blood glucose in four Amazon fishes. Journal of Aquaculture in the Tropics, 20: 101-110.

Gomes, L.C.; Chagas, E.C.; Brinn, R.P.; Roubach, R.; Coppati, C.E.; Baldisserotto, B.; 2006. Use of salt during transportation of air breathing pirarucu juveniles (Arapaima gigas) in plastic bags. Aquaculture, 256: 521-528.

Gomes, L.C.; Roubach, R.; Cavero, B.A.S.; Pereira-Filho, M.; Urbinati, E.C. 2003. Transport of pirarucu Arapaima gigas juveniles in plastic bag. Acta Amazonica. 33: 631-636.

Goulding, M.; Barthem, R.; Ferreira, E.J.G.; 2003. The Smithsonian atlas of the Amazon. Smithsonian Institution Press, Washington, DC.
Hrbek, T.; Farias, I.P.; Crossa, M.; Sampaio, I.; Porto, J.I.R.; Meyer, A. 2005. Population genetic analysis of Arapaima gigas, one of the largest freshwater fishes of the Amazon basin: implications for its conservation. Animal Conservation, 8: 297-308.

Imbiriba, E.P. 2001. Potencial da criação de pirarucu, Arapaima gigas, em cativeiro. Acta Amazonica, 31: 299-316.

Kampen, E.J.; Zijlstra, W.G. 1964. Erythrocytometric methods and their standartization. Clinica Chimica Acta, 6: 538-542.

Mommsen, T.P.; Vijayan, M.M.; Moon, T.W. 1999. Cortisol in teleosts: dynamics, mechanisms of action, and metabolic regulation. Reviews in Fish Biology and Fisheries, 9: 211-268.

Morales, A.E.; Cardenete, G.; Abellán, E.; García-Rejón, L. 2005. Stress-related physiological responses to handling in common dentex (Dentex dentex Linnaeus, 1758). Aquaculture Research, 36: $33-40$

Nickum, J.G.; Bart, H.L.; Bowser, P.R.; Greer, I.E.; Hubbs, C.; Jenkins, J.A.; MacMillan, J.R.; Rachlin, J.W.; Rose J.D.; Sorensen, P.W.; Tomasso, J.R. 2004. Guidelines for the use of fishes in research. American Fisheries Society, Bethesda, MD.

Pereira-Filho, M.; Cavero, B.A.S.; Roubach, R.; Ituassú, D.R.; Gandra, A.L.; Crescêncio, R. 2003. Cultivo do pirarucu (Arapaima gigas) em viveiro escavado. Acta Amazônica, 33: 715-718.

Sloman, K.A.; Taylor, A.C.; Metcalf, N.B.; Gilmour, K.M.; 2001. Stress from air immersion fails to alter chloride cell numbers in the gills of rainbow trout. Journal of Fish Biology, 59: 186-190.

Sumpter, J.P. 1997. The endocrinology of stress. In: Iwama, G.K.; Pickering, A.D.; Sumpter, J.P.; Schreck, C.B. (Eds.), Fish stress and health in aquaculture. Society for Experimental Biology Seminar Series 62, Cambridge University Press, Cambridge, pp. 95-118.

Vijayan, M.M.; Moon, T.W. 1994. The stress response and plasma disappearance of corticosteroid and glucose in a marine teleost, sea raven. Canadian Journal of Zoology, 72: 379-386.

Vijayan, M.M.; Pereira, C.; Grau, E.G.; Iwama, G.K. 1997. Metabolic responses associated with confinement stress in tilapia: the role of cortisol. Comparative Biochemistry and Physiology, 116C: 89-95.

Wendelaar Bonga, S.E. 1997. The stress response in fish. Physiological Reviews. 77, 591-625.

Wedemeyer, G.A. 1996. Physiology of fish in intensive culture systems. Chapman and Hall, New York, NY.

Recebido em 22/03/2007

Aceito em 31/08/2007 
